and iron electrodes and toxicity evaluation. Water Science \& Technology. 2019. P. 1-11.

9. Quaissa Y. A., Chabani M., Amrane A. and Bensmaili A. Removal of tetracycline by electrocoagulation: Kinetic and isotherm modeling through adsorption. Journal of Environmental Chemical Engineering. 2, 1. 2014. P. 177-184.

10. Marugananthan M., Bhaskar Raju G., Prabhakar S. Separation of pollutants from tannery effluents by electro flotation. Separation and Purification Technology. 40, 1. 2004. P. 69-75.

11. Zongo I., Maiga A. H., Wethe J., Valentin G., Leclerc J. P., Paternotte G., Lapicque F. Electrocoagulation for the treatment of textile wastewaters with $\mathrm{Al}$ or Fe electrodes: compared variations of COD levels, turbidity and absorbance. Journal of Hazardous Materials. 169, 1-3. 2009. P. 70-76.

12. Changmai M., Pasawan M., Purkait M. K. Separation and purification technology treatment of oily wastewater from drilling site using electrocoagulation followed by microfiltration. Separation and Purification Technology. 210. 2019. P. 463-472.

DOI https://doi.org/10.30525/978-9934-26-183-1-12

\title{
ВПЛИВ ІОНІВ МІДІ НА ПАРОСТКИ ЯЧМЕНЮ
}

Січняк О. Л.

кандидат біологічних наук, дочент, доиент кафедри генетики та молекулярної біології Одеський національний університет імені I. I. Мечникова

Мірось С. Л.

кандидат біологічних наук, дочент, доиент кафедри генетики та молекулярної біології Одеський національний університет імені I. I. Мечникова

Білоконь С. В.

кандидат біологічних наук, дочент, доиент кафедри генетики та молекулярної біології Одеський національний університет імені I. I. Мечникова м. Одеса, Украӥна

Останнім часом проблема забруднення довкілля стала глобальною. Широке використання фунгіцидів, які містять мідь, призводить до іiі 46 
накопичення у грунтах та змиву у природні водойми. Мідь $є$ фізіологічно значущім мікроелементом, потрібним рослинам, але стає токсичною при високих концентраціях [1]. Одним зі шляхів вирішення проблеми забруднення $\epsilon$ здійснення біологічного моніторингу, який дає інтегральну оцінку наслідків для живої природи дії комплексу забруднювачів.

Метою даної роботи є визначення впливу підвищених концентрацій (1 і 8 ГДК) іонів міді (яка є також фізіологічно значущім мікроелементом) на процес формування паростків ячменю, які розглядали як можливі тест-об'єкти. Використовували п'ять сортів ярого ячменю, створених у Селекційно-генетичному інституті - національному центрі насіннєзнавства і сортовивчення [2]: Галактик, Південний, Гетьман, Командор, Всесвіт.

Для оцінки реакції ячменю використовували $\mathrm{Cu}\left(\mathrm{NO}_{3}\right)_{2}$, який добре розчиняється у воді, а його молекули дисоціюють на іони. Іони нітрату не мають токсичної дії на рослинний організм i $\epsilon$ елементами мінерального живлення рослин. Тому усі прояви пригнічення рослин можна віднести на рахунок дії іонів міді. Концентрації розраховували 3 огляду на гранично допустиму концентрацію (ГДК) іонів міді грунтах 55 мг/кг [3]. Розчин нітрату міді у концентрації 8,6*10 ${ }^{-4}$ моль/л містить іони міді у кількості 55 мг/кг, що дорівнює одній ГДК. Інша концентрація відповідала величині у 8 ГДК $\left(6,9 * 10^{-3}\right.$ моль/л). Насіння пророщували на фільтрувальному папері у чашках Петрі у зазначених розчинах солей у порівнянні 3 пророщуванням у воді (контроль). Враховували енергію проростання і схожість насіння, довжину пагону паростка і довжину кореня. Для порівняння зразків використовували індекс толерантності (і.т. - відношення проказника за дії іонів міді до показника у контролі, виражене у відсотках). Досліджували також мітоз в кореневій меристемі паростків у порівнянні 3 контрольною групою згідно стандартним методикам.

За концентрації 1 ГДК у більшості досліджуваних сортів достовірно зменшувалася енергія проростання (і.т. 87-89\%) і схожість насіння (i.т. 88-89\%). При збільшенні концентрації до 8 ГДК пригнічення енергії проростання (і.т. 51-58\%) і схожості насіння (і.т. 54-58\%) відбувалося у ще більшому ступені. Суттєвих відмінностей між сортами за енергією проростання і схожістю насіння не виявлено. За обох досліджуваних концентрацій достовірно пригнічувався ріст коріння паростків. Найбільш толерантним до дії іонів двовалентної міді виявилися паростки ячменю Всесвіт (і.т. 89\% за 1 ГДК і 46\% за 8 ГДК). Найбільш чутливими були паростки ячменю Південний (і.т. 54\% і 15\%, 
відповідно). Паростки інших сортів показали проміжну толерантність. У реакції за довжиною пагонів паростків за дії міді сортових особливостей не виявлено. Ріст пагонів достовірно пригнічувався за 1 ГДК (i.т. 81-90\%), а за 8 ГДК ступінь пригнічення росту пагонів суттєво збільшувався (і.т. 55-67\%).

Дослідження мітозу в кореневій меристемі паростків показало, що за 1 ГДК знижувався мітотичний індекс (і.т. 59-74\% за 1 ГДК і 37-51\% за 8 ГДК), що кореспондувало із пригніченням росту кореневої системи паростків. Найбільш чутливим до міді знов виявися сорт Південний, який мів найменші значення мітотичного індексу. За дії міді збільшувалася частота клітин 3 абераціями, яка склала 1,8-2,4\% для

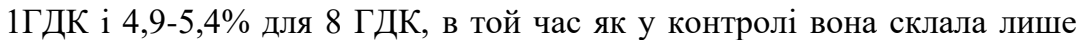
0,4\%. Серед клітин 3 абераціями спостерігали мітози 3 відставанням хромосом, мостами та фрагментами, в контролі - поодинокі клітини 3 мостами та 3 відставанням хромосом. Зменшення проліферативної активності клітин кореня та індукція різноманітних хромосомних аберацій за дії іонів міді та інших важких металів відмічалося й в інших дослідженнях [4]. Ці зміни можуть бути обумовлені взаємодією міді 3 ДНК. Під впливом високих концентрацій міді спостерігається дестабілізація вторинної структури ДНК у розчині. Іони $\mathrm{Cu}^{2+}$ значно активують реплікаційні та транскрипційні процеси, можливо завдяки частковій денатурації ДНК [5]. Вважають що при стресі $\mathrm{Cu}^{2+}$ відбувається індукція зупинки росту коріння внаслідок «загального» сигналу, який вмикає окиснювальні посттрансляційні модифікації специфічних білків клітинного циклу [6].

Відмічалося також зниження біомаси коренів рослин внаслідок перекісного окиснення ліпідів [7]. Звичайним результатом дії важких металів $€$ надмірне накопичення метилгліоксалю та активних форм кисню, які можуть руйнувати ліпіди, клітинні мембрани та ДНК, окислювати білки та інактивувати ферменти. Вищі рослини використовують складну систему захисту та гліоксалази для пом'якшення негативних ефектів зазначених речовин. Крім того, важкі метали можуть звязуватися органічними кислотами, амінокислотами, глутатіоном або металзв'язуючими лігандами [8].

Коріння паростків виявилося найбільш чутливим до дії іонів міді. Адже це основні ворота проникнення отрути у рослинний організм i, разом 3 тим, потужний фільтр, який захищає інші органи i тканини рослинного організму, що розвивається. Тому і сортові відмінності за реакцією на важкі метали виявлені лише у корінні. А у пагонах паростків, завдяки дії захисних механізмів у кореневій тканині 
негативний вплив нівелюється, шкодо чинність стає меншою і сортових відмінностей виявити не вдалося. Коріння ж сприймає перший удар, який діє на генетичний апарат клітин, репараційні процеси в ньому, впливає на ефективність роботи ферментних систем та проникливість мембран - на основні фенотипові ознаки, від яких залежить життєздатність і які знаходяться під безпосереднім контролем генотипу, а отже зберігається можливість проявлення сортових відмінностей в реагування паростків на дію важких металів.

\section{Висновки.}

Ячмінь Hordeum vulgare L. відповідає вимогам, які висуваються до тест-об'єктів. За дії іонів міді спостерігали зменшення енергії проростання і схожості насіння, пригнічення росту коренів і пагонів паростків. Пригнічення росту коріння та пагонів паростків прямо пропорційне концентрації іонів міді, причому коріння страждало у значно більшому ступеню, ніж пагін. У реакції кореневої системи паростків ячменю на дію іонів міді виявлені сортові відмінності. Найбільш чутливими до дії іонів міді були паростки сорту Південний, а найбільш толерантними - паростки сорту Всесвіт.

\section{Література:}

1. Asati, A., Pichhode, M., and Nikhil, K. Effect of heavy metals on plants: an overview. Int. J. Appl. Innov. Eng. Manage. 2016. № 5. 2319-4847.

2. Каталог сортів та гібридів Селекційно-генетичного інституту. Одеса, 2011. 128 с.

3. Рідей Н.M., Наумовська O.І., Бережняк Е.М., Паламарчук С.П. Основи сільськогосподарської екології. Методичні рекомендації для проведення лабораторно-практичних робіт. Київ: НАУ, 2008. 106 с.

4. Ульяненко Л.Н., Рева Е.В., Сынзыныс Б.И. Цитогенетические эффекты у Allium cepa L. при раздельном и сочетанном действии $\mathrm{Cu}, \mathrm{Zn}$ и Ni. Сельскохозяйственная биология. 2017. Т. 52, № 1. С. 183-190. doi: 10.15389/agrobiology.2017.1.183rus

5. Covindaraju M., Shekar H.S., Sateesha S.B., Raju P.V., Sambasiva K.R., Rao R.K.S.J. , Rajamma A.J. Copper interactions with DNA of chromatin and its role in neurodegenerative disorders. J. of Pharmaceutical Analisis. 2013 V. 3. P. 354-359. https://doi.org/10.1016/j.jpha.2013.03.003

6. Pena L.B., Méndez A.A.E., Matayoshi C.L., Zawoznik M.S., Gallego S.M. Early response of wheat seminal roots growing under copper excess. Plant Physiology and Biochemistry. 2015. V. 87. P. 115-123. https://doi.org/10.1016/j.plaphy.2014.12.021. 
7. Vidal C., Ruiz A., Ortiz J., Larama G., Perez R., Santander C., Ferreira P., Cornejo P. Antioxidant Responses of Phenolic Compounds and Immobilization of Copper in Imperata Cylindrica, a Plant with Potential Use for Bioremediation of $\mathrm{Cu}$ Contaminated Environments. Plants. Basel, Switzerland. 2020. V. 9 (10). P. 1397. https://doi.org/10.3390/plants9101397

8. Delangiz N., Khoshru B., Asgari Lajayer B., Ghorbanpour M., Kazemalilou S. Molecular Mechanisms of Heavy Metal Tolerance in Plants. Cellular and Molecular Phytotoxicity of Heavy Metals. Nanotechnology in the Life Sciences. 2020. P 125-136. https://doi.org/10.1007/978-3-03045975-8_8

DOI https://doi.org/10.30525/978-9934-26-183-1-13

\title{
ІДЕНТИФІКАЦІЯ НАФТОПРОДУКТІВ
}

\author{
Троценко О. В. \\ аспірант кафедри технології переробки нафти, \\ газу та твердого палива \\ Національний технічний університет \\ «Харківський політехнічний інститут»
}

Григоров А. Б.

доктор технічних наук,

дочент кафедри технології переробки нафти, газу та твердого палива Національний технічний університет

«Харківський політехнічний інститут»

м. Харків, Україна

Забруднення навколишнього середовища об'єктами техносфери на сьогоднішній день $\epsilon$ значною проблемою, що набула глобального характеру і яка потребує свого своєчасного вирішення. Це, у свою чергу, враховується при формуванні державної політики країн Європейського Союзу (СС) в галузі охорони навколишнього середовища, де особливу роль відведено забезпеченню екологічної безпеки країни в цілому, що складається 3 заходів по збереженню природних систем і здоров'ю населення [1, с. 12]. При реалізації екологічної політики $€ C$ значну увагу приділяють контролю вмісту нафтопродуктів у літосфері та гідросфері, які є помірно та мало небезпечними речовинами (III або IV клас 